IRSH 50 (2005), Supplement, pp. 2 I9-246 DOI: I0. I0I7/S0020859005002 I 29

(C) 2005 Internationaal Instituut voor Sociale Geschiedenis

\title{
Migration and Endogamy According to Social Class: France, I $803-1986^{*}$
}

\author{
Jean-Pierre Pélissier, Danièle Rébaudo, Marco \\ H.D. van LEEUWEN, AND INEKE MaAs
}

SumMARY: Does intra-national migration matter for partner choice? A number of conflicting hypotheses on the effects of migration on the likelihood of endogamy according to social class of origin are formulated and tested on the French historical record over the past two centuries. We conclude that migrants were less likely to marry endogamously, especially if they migrated from rural villages to cities; this is explained mainly by the fact that they thereby escaped the social pressure of their parents and peers and met more people from different social backgrounds. Contrary to what we expected, the relationships between migration characteristics and endogamy changed hardly at all over the two centuries. We also investigated whether temporal differences in endogamy could be explained partly by changes in migration patterns. We found that they could. The increase in the number of men and women living in or moving to cities was one particularly important cause of the decreasing likelihood of endogamy. Finally, we were interested in the possible bias in regional studies on endogamy. Our results show that this bias is especially large if these regions include only rural areas or cities. This is because the likelihood of endogamy differs between rural areas and cities, and is also especially low for people who move between these two types of region.

\section{INTRODUCTION}

During young adulthood, finding an attractive partner is one of the main aims of life. People go to great lengths to fulfil this aim. Some "try out" several partnerships before they settle, others search for a long time until they find their true love. Some marry their neighbour's son or daughter, with whom they played as a child; others migrate and meet someone in their new place of residence who finally becomes their partner. It is this

* We would like to thank Marie-Pierre Arrizabalaga, Margarida Duraes, Antoinette FauveChamoux, Leslie Page Moch, Elyce Rotella, Frank van Tubergen, and Richard Zijdeman for their valuable comments on an earlier draft of this article, as well as the participants of two seminars where this paper was discussed: a seminar on "Familles, mariages et domesticités: modèles historiques comparés $\left(\mathrm{XVI}^{\mathrm{e}}-\mathrm{XX}^{\mathrm{e}}\right.$ siècle)" at the École des Hautes Études en Sciences Sociales in Paris, and the Utrecht Mobility and Stratification Seminar. 
difference that is the topic of this article. Does intra-national migration matter for partner choice? And, more specifically, does it matter for the likelihood that the marriage will be endogamous, i.e. that both partners originate from the same social class?

Many studies have shown that people tend to marry over a short geographical distance. ${ }^{\mathrm{I}}$ At first sight it seems likely that their marriage will be endogamous because neighbours tend to be from the same social class. However, one could also argue that long-distance marriages are more likely to be endogamous because a partner found at a great geographical distance might indicate a large investment in searching for a partner, and therefore an especially close fit between the partners. Alternatively, the long-distance migration might have been triggered by something totally unrelated to searching for a spouse, such as further education or finding a job. A number of conflicting hypotheses on the effects of migration on the likelihood of endogamy will be examined in this article.

In the following we will study the consequences of migration for endogamy by class of origin in France between I 803 and I986. The choice of spouse has been the topic of a great many quantitative historical studies, in France as well as elsewhere, but they have tended to focus on geographical endogamy or on age differences between spouses. ${ }^{2}$ The same applies to qualitative historical studies on marriage patterns, such as those by Flandrin and Segalen. ${ }^{3}$ More attention has been paid to the study of class mobility in sociological studies of post-World-War-II France. ${ }^{4} \mathrm{~A}$ few

I. See, for example, Alice Bee Kasakoff and John W. Adams, "Spatial Location and Social Organisation: An Analysis of Tikopian Patterns”, Man, New Series, I 2 (1977), pp. 48-64; Barrie S. Morgan, "A Contribution to the Debate on Homogamy, Propinquity, and Segregation", Journal of Marriage and the Family, 43 (198I), pp. 909-921; Thomas W. Pullum and Andres Peri, "A Multivariate Analysis of Homogamy in Montevideo, Uruquay", Population Studies, 53 (1999), pp. 36I-377; Gillian Stevens, "Propinquity and Educational Homogamy", Sociological Forum, 6 (1991), pp. 715-726.

2. See inter alia Guy Brunet, Antoinette Fauve-Chamoux, and Michel Oris (eds), Le choix $d u$ conjoint (Paris, 1996).

3. J.L. Flandrin, Les amours paysannes XVIe-XIXe siècles (Paris, 1975), and Martine Segalen, Love and Power in the Peasant Family: Rural France in the Nineteenth Century (Oxford, 1983). 4. See for instance Michel Bozon and François Héran, "La découverte du conjoint. I. Évolution et morphologie des scènes de rencontre", Population, 6 (1987), pp. 943-986; idem, "La découverte du conjoint. II. Évolution et morphologie des scènes de rencontre”, Population, I (1988), pp. I2 I-I 50; idem, "L'aire de recrutement du conjoint", Données sociales (1987), pp. $33^{8-347}$. See too Michel Forsé and Louis Chauvel, "L'évolution de l'homogamie en France", Revue française de sociologie, 36 (1995), pp. 123-142; Alain Girard, Le choix du conjoint. Une enquête psycho-sociologique en France (Paris, I98 I); Louis-André Vallet, "Forty Years of Social Mobility in France: Change in Social Fluidity in the Light of Recent Models", Revue Française de Sociologie: An Annual English Selection, 42, Supplement (2001), pp. 5-64; and various studies by Singly, including his recent study of France, and other European studies. François de Singly and Vincenzo Cicchelli, "Contemporary Families: Social Reproduction and Personal Fulfilment', in D.I. Kertzer and M. Barbagli (eds), Family Life in the Twentieth Century: The History of the European Family (New Haven, CT, 2003), pp. 3 I I-349. 
articles deal with the integration of migrants in parts of France, based on either the conscription registers 5 or marriage records. ${ }^{6}$

We used the large TRA dataset for the purpose of our present investigation.7 This dataset is especially suitable for our study. First, because France is a relatively large country we will be able to study the consequences of both short-distance and long-distance migration. Secondly, the long period allows us to study whether the consequences of migration have changed with the almost universal availability of modern means of transport, and also whether temporal differences in endogamy can be explained, in part at least, by variations in the occurrence of migration. Thirdly, because the data cover both urban and rural regions we can investigate whether the direction in which one migrates matters.

Methodologically, this study might be useful because many historical studies on endogamy are restricted to stable populations in a specific area. By investigating the effects of migration on endogamy it will become possible to evaluate to what extent the results of regionally restricted studies are biased. From a societal point of view it is interesting to see to what extent migrants integrate into their new region of residence. If the marriages of migrants are less likely to be socially endogamous than those of non-migrants, and especially if they are more likely to marry downward, this can be seen as a sign of imperfect integration.

\section{ENDOGAMY AND MIGRATION: RECENT THEORIES}

Whether migrants win or lose on the social ladder has been the subject of a

5. Jean-Claude Farcy and Alain Faure, La mobilité d'une génération de français. Recherches sur les migrations et les déménagements vers et dans Paris à la fin du XIXe siècle (Paris, 2003).

6. Antoine Prost, "Structures sociales du XVIIIe arrondissement en 1936", in J. Girault (ed.), Ouvriers en banliene, XIXe-XXe siècles (Paris, I998), pp. 50-64. Philippe Rygiel, "Dissolution d'un groupe ethnique. Origines des témoins et des conjoints des enfants des familles polonaises implantées dans le Cher", Mouvement Sociale, I9I (2000), pp. 69-89.

7. On TRA, see Jacques Dupâquier and Jean-Pierre Pélissier, "Mutations d'une société: la mobilité professionelle”, in J. Dupâquier and D. Kessler (eds), La société française au XIXe siècle (Paris, 1992), pp. I2 I-236; C. Motte and J.-P. Pélissier, "La binette, l'aiguille et le plumeau", in ibid., pp. 237-342; J.-P. Pélissier and D. Rébaudo, "Une approche de l'illettrisme en France", Histoire et Mesure, I9 (2004), pp. 16I-202. On studies of migration and marriage using the TRA data, see Didier Blanchet and Dennis Kessler, "La mobilité géographique de la naissance au mariage", in Dupâquier and Kessler, La société française an XIXe siècle, pp. 343-378; PaulAndré Rosental, Les sentiers invisibles. Espace, familles et migrations dans la France du I ge siècle (Paris, I999); idem, "La migration des femmes (et des hommes) en France au XIX e siècle", Annales de Démographie Historique, I (2004), pp. I07-136. See also Noël Bonneuil and PaulAndré Rosental, "Changing Social Mobility in Nineteenth-Century France", Historical Methods, 32 (1999), pp. 53-73, and Jérôme Bourdieu, Gilles Postel-Vinay, and Akiko SuwaEisenmann, "Défense et illustration de l'enquête des 3000 familles. L'exemple de son volet patrimonial”, Annales de Démographie Historique, I (2004), pp. I9-52. 
number of sociological ${ }^{8}$ studies, and several historical studies, mostly by American historians working with census data. Thernstrom assumed the existence of a "permanent floating proletariat" in America in the nineteenth century, an "underclass" of men, permanently on the move to nowhere. 9 This image has been strong and persistent, despite statistical reanalyses of Thernstrom's work which reached quite different conclusions. ${ }^{1 \circ}$ Upton, Kousser, and others stress that the likelihood of social advancement after migration depends on rational factors, notably age: the younger one is at migration, the longer one has to reap what has been sown, that is to recapture the "costs" of migration. Other, more recent studies on careers in the past have also stressed factors such as age and schooling. ${ }^{\text {II }}$ This reappraisal of migrants can, in fact, be seen as part of a broader movement in the historiography of the Western world. Where migrants were once seen as a marginal minority of losers, it is now common to claim that migration was not marginal at all but touched the lives of a great many Europeans, possibly the majority, and that as a consequence there was no such thing as a selection effect of an underclass of less talented men and women who would always be less fortunate than the rest. ${ }^{\mathrm{I} 2}$

What migration meant for the family domain, however, is still largely unknown. Broadening the study of the consequences of migration from the economic to the family domain is interesting not only for methodological and societal reasons, as discussed above, but also for theoretical reasons. Theoretical progress can be made by systematically comparing

8. See for example John L. Rodgers and Joan R. Rodgers, "The Economic Impact of Rural-toUrban Migration in the United States: Evidence for Male Labor-Force Participants", Social Science Quarterly (1997), pp. 937-954, and Michael Wagner, "Zur Bedeutung räumlicher Mobilität für den Erwerbsverlauf bei Männern und Frauen”, in Akademie für Raumforschung und Landesplanung (ed.), Regionale und biographische Mobilität im Lebensverlauf (Hanover, I992), pp. I49-I67.

9. S. Thernstrom, The Other Bostonians: Poverty and Progress in the American Metropolis I880-1970 (Cambridge, MA, I973), pp. 40-42, 23 I-232.

ı. J. Morgan Kousser, "Log-linear Analysis of Contingency Tables: An Introduction for Historians with an Application to Thernstrom on the "Floating Proletariat", Historical Methods, I5 (1982), pp. I 52-I69. Graham J.G. Upton, "A Note on 'Log-linear Analysis of Contingency Tables”, Historical Methods, i 8 (1985), pp. I47-I 54.

I I. For a survey see John C. Brown, Marco H.D. van Leeuwen, and David Mitch, "The History of the Modern Career: An Introduction", in David Mitch, John C. Brown, and Marco H.D. van Leeuwen (eds), Origins of the Modern Career (Ashgate, 2004), pp. 3-4I.

I2. See for example, Leslie Page Moch, Moving Europeans: Migration in Western Europe since I650 (Bloomington, IN, I992); Colin Pooley and Jean Turnbull, Migration and Mobility in Britain since the I 8th Century (London, 1998), and the discussion of their book in the Annales de Démographie Historique in 2002 by Lucassen, Kasakoff, Kok, and Schwartz: Leo Lucassen, "Introduction", Annales de Démographie Historique (2002), pp. I0I-I05; Jan Kok, "Comment on Pooley and Turnbull”, ibid., pp. I I3- I I 8; Robert M. Schwartz, "Steady State Mobility", ibid., pp. II9-I23. See also Anne Winter, “'Vagrancy' as an Adaptive Strategy: The Duchy of Brabant”, International Review of Social History, 49 (2004), pp. 249-278. 
competing hypotheses from several theories, and, as we will see below, several partly conflicting hypotheses on the consequences of migration for endogamy can be derived. Furthermore, differences with respect to endogamy between migrants and non-migrants might add to the explanation of regional and temporal differences in the likelihood of endogamy if these regions or periods vary in terms of the extent of migration. These regional and temporal differences have been the focus of much research on endogamy. ${ }^{13}$

Why would we expect migrants to show more or less endogamy than non-migrants? In general, social endogamy is thought to be the consequence of, first, people's preferences for a partner from the same social class; second, the pressure of significant others (parents, peers, the priest for example) on one to marry within one's own social class; and, third, social segregation, making it more likely that one meets and consequently marries someone from one's own class. ${ }^{14}$ If migrants differ from non-migrants with respect to one or more of these determinants of endogamy, we may expect the two groups to differ too with respect to the likelihood of endogamy. Research on the effects of international migration on integration, however, has shown that it makes sense not only to distinguish between migrants and non-migrants but also to look at the characteristics of the place of destination and the place of origin of migrants and the specific combination of the two (the distance between place of origin and destination for example). ${ }^{\text {Is }}$

In the literature on migration and endogamy we found one hypothesis that predicts a direct effect of migration on partner preferences. According to Sherkat, endogamy might be more attractive for people who have been uprooted. ${ }^{16}$ They feel strangers in their place of destination and try to compensate for this by seeking friends and a partner who will make them feel at home. This is likely to be someone with the same social origins as themselves. We extend this hypothesis because we expect individuals who move over a larger distance to feel more uprooted and therefore even more likely to seek a partner from their own social class (Нia). Additionally, the effect of migration might be greater if the place of origin and destination

I3. See for example, Robert D. Mare, "Five Decades of Educational Assortative Mating", American Sociological Review, 56 (1991), pp. I 5-32; Wilfred Uunk, "Who Marries Whom? The Role of Social Origin, Education and High Culture in Mate Selection of Industrial Societies during the Twentieth Century" (Ph.D., University of Nijmegen, 1996).

I4. M. Kalmijn, "Intermarriage and Homogamy: Causes, Patterns, Trends", Annual Review of Sociology, 24 (1998), pp. 395-42 I.

I s. Frank van Tubergen, "The Social-cultural and Socio-economic Integration of Immigrants in Cross-National Perspective: Origin, Destination, and Community Effects" (Ph.D., University of Utrecht, 2005).

16. Darren E. Sherkat, "Religious Intermarriage in the United States: Trends, Patterns, and Predictors", Social Science Research, 33 (2004), pp. 606-625. 
are less alike (Hib). Someone who moves from a small village to another small village probably feels less alone than someone who moves from a small village to a city, or vice versa. Sherkat's hypothesis would also be supported if people who were uprooted for reasons other than migration were also more likely to marry endogamously. We will therefore investigate whether men and women were more likely to marry endogamously in the years immediately after the end of a war than in times of peace (Hic).

While being uprooted as a consequence of migration is thought to increase endogamy, there are also scholars who claim that, for an altogether different reason, migration will decrease endogamy according to social origin. It is sometimes assumed that individuals who are ambitious and highly motivated in their occupational career will also be more eager to escape their social class of origin by marrying upward (i.e. not endogamously). The research on the economic consequences of migration shows that it is unclear whether migrants are in general positively selected with respect to characteristics such as ambition, capacities, and intelligence. ${ }^{17}$ However, certain circumstances might favour the positive selection of migrants.

Such a positive selection tends to be stronger if people migrate for economic reasons rather than family or political reasons. Even if we do not know why people migrate, we may assume that migration from rural to urban regions is more likely to be economically motivated than migration in the opposite direction or migration between rural areas or between urban regions. Positive selection is also more likely if people migrate over a longer distance. Such migration requires a relatively large investment. Highly motivated individuals who expect to be able to compensate for this investment in the future will be more inclined to take this risk than those who do not. We therefore expect less endogamy among long-distance migrants $\left(\mathrm{H}_{2} \mathrm{a}\right)$ and among migrants moving from rural to urban regions ( $\left.\mathrm{H}_{2} \mathrm{~b}\right)$.

These effects would disappear if we could take these selections into account. We cannot do this with the data at hand, except in the following, admittedly restricted, way by distinguishing the intergenerationally upward mobile from those in the same class or an even lower class than their father. We assume that the intergenerationally upward mobile are more ambitious and therefore more likely to marry exogamously than the latter $\left(\mathrm{H}_{2} \mathrm{c}\right)$.

Social pressure, the second determinant of endogamous marriages, might be directly affected by migration. The larger the distance migrated, the more difficult it is for parents or peers to effectively influence the 
behaviour of the migrant $\left(\mathrm{H}_{3} \mathrm{a}\right) .{ }^{{ }^{8}}$ Again, however, it is useful to look at the characteristics of the place of origin and place of destination of the migrant.

Social control of the choice of marriage partner in the French countryside has often been described. Unmarried youngsters would have met long before the age of courtship, either on the farm, during work evenings in the village, as members of local fraternities, in the fields during sowing and reaping, at feasts and fairs, in church during Mass, or at school. Work evenings - in French veillées - were common throughout the countryside. ${ }^{19}$ In the long winter evenings, the unmarried girls of the village, their mothers, and potential suitors would join one another in a communal barn to work, mostly to spin, sing and talk, perhaps dance, and to eat and drink. What the ballroom was for the urban jeunesse dorée, the veillée was for rural populations, except that the former had leisure, while the latter also had to work. It is often said that marriages were made in the veillée: "the spinning-room gave the lads an opportunity to observe the girls' abilities at what would be one of their most important tasks in the household. In a traditional rural society, such criteria were extremely important for the choice of a partner." 20

Not only was social control in evidence during the veillées, it pervaded village life and it favoured endogamy, as has often been noted with regard to geographical endogamy and sometimes social endogamy. Many proverbs expressed a desire for endogamy in the countryside, and none disapproved of it: ${ }^{21}$ "Qui se marie loin trompe ou est trompé (Provence); Épouse ton voisin, tu connaîtras son chien (Gascogne, Languedoc)". ${ }^{22}$ As elsewhere in Europe, village youngsters accepted this collective oral wisdom and protected the stock of unmarried men and women by beating up "outsiders" (unless they had, literally, been bought off). "Fools" who were courting outside their age group, their village, or social group were paraded through the village sitting back to front on a donkey; another technique was to deposit a trail of rotting vegetables or manure between the houses of the two lovers. Intense staring and vile gossiping by the women at the communal washing place or a rough charivari in front of the houses of the culprits were also used to express disapproval. ${ }^{23}$ In the very

I8. Sherkat, "Religious Intermarriage in the United States".

19. M. Mitterauer, A History of Youth (Oxford, 1990), pp. 178-i84. Edward Shorter, The Making of the Modern Family (New York, 1975), pp. I25-I 27.

20. Mitterauer, A History of Youth, p. I8 1 . See too, Segalen, Love and Power in the Peasant Family, p. I6.

2 I. Flandrin, Les amours paysannes, p. 139.

22. Martine Segalen, De l'amour et du mariage autrefois (Paris, I98 I), p. 34.

23. Flandrin, Les amours paysannes, pp. I40-145; Segalen, Love and Power in the Peasant Family; Eugene Weber, Peasants into Frenchmen: The Modernization of Rural France 1870I9I4 (Stanford, CA, I976), pp. 399-4I3. See too the articles in Jacques Le Goff and Jean-Claude Schmitt (eds), Le charivari (Paris, I98 I). 
many small villages in France in the nineteenth century, the village might to a large extent consist of family and so, it has been claimed, it was the families who did the marrying rather than the couples themselves. ${ }^{24}$

In cities, social pressure and control is presumably less effective than in rural areas. ${ }^{25}$ Migrants who moved from a village to the city were therefore, by and large, less subject to social control, although we know that migrants from the same region often flocked together and so did not entirely escape this control. ${ }^{26}$ Indeed, the presence of kin might have been an impetus to migrate to a particular town, ${ }^{27}$ and one might also have migrated as a young child with one's parents to a town. Nonetheless, one might expect migration from rural to urban areas to weaken social control and thus endogamy $\left(\mathrm{H}_{3} \mathrm{~b}\right)$.

Migrants moving in the other direction might, however, leave behind a relatively tolerant climate and move to a situation where neighbours watch one another closely. In this case, social pressure to marry an appropriate partner (i.e. from the same social class) might decrease to a much lesser extent, or even increase. ${ }^{28} \mathrm{We}$ expect that a similar mechanism might make first marriages more likely to be endogamous than later marriages $\left(\mathrm{H}_{3} \mathrm{c}\right)$. Social pressure from family and peers is probably much more effective and stronger for first marriages than for second marriages, because in the latter case the bride and groom no longer live with their parents; they are older, and more independent. Social pressure might also be especially high in regions with traditional family values $\left(\mathrm{H}_{3} \mathrm{~d}\right)$.

Alternatively, individuals who experienced little social control might also be more likely to migrate than those experiencing a great degree of social control. Where families exercised little control, their children might be more likely to marry outside their own social class and to leave their place of origin. The less social control, the further children would migrate both with respect to distance $\left(\mathrm{H}_{4} \mathrm{a}\right)$ and with respect to urbanization $\left(\mathrm{H}_{4} \mathrm{~b}\right)$; and the more likely it is that they would marry exogamously. We expect these effects to disappear if the strength of social control within the family and at the place of origin is taken into account.

Examples of families with little control over their children might include incomplete families $\left(\mathrm{H}_{4} \mathrm{c}\right)$ and families without much capital $\left(\mathrm{H}_{4} \mathrm{~d}\right)$. The first have more difficulty in influencing the behaviour of their children because two parents can do that more effectively than one parent. The second type of family has less influence because they cannot threaten to disinherit their children if they refuse to conform. It has been argued that

24. Weber, Peasants into Frenchmen, pp. 167-168.

25. Louise Tilly and Joan Scott, Women, Work and Family (New York, I978), pp. I2 I-I 22.

26. See for example Weber, Peasants into Frenchmen, pp. 28I-282.

27. Leslie Page Moch, Paths to the City (Thousand Oaks, CA, 1983), pp. 199-200.

28. Sherkat, "Religious Intermarriage in the United States". 
the extent to which social control was exerted was closely linked to the transmission of property down the generations. This was one reason for the high degree of social control among farmers: they had to ensure that the farm remained intact over centuries. Segalen writes:

In traditional society, problems that would today be considered personal, whether to do with the intimacies of the heart or of the body, were the responsibility of the community. The formation of the couple, as well as concerning the young people themselves, involved the two families and the entire social group. ${ }^{29}[\ldots]$ Family considerations weigh heavily on the individuals who, tend to disappear in the face of the wider aims of economic and social improvement of the family line. In these terms the couple is merely a link in the chain leading to the growth of patrimony or resisting the fragmentation of landholdings through inheritance. The individuality of the couple, or rather, its tendency towards individuality, is crushed by the family institution, and also by the social pressure exercised by the village community as a whole. $3^{\circ}$

This is also said to be the case for the propertied classes in the city: "Curieusement le modèle bourgeois se rapproche du modèle paysan, dans la mesure où l'institution matrimoniale coïncide avec un 'établissement'. $\mathrm{Au}$ mariage, les parents transmettent une partie de leurs biens à leurs enfants; ils doivent donc en contrôler soigneusement la formation." ${ }^{\mathrm{I}}$

If regions are relatively homogeneous with respect to social class, social endogamy within a certain region will result even if people do not prefer to have spouses with characteristics similar to their own. ${ }^{32}$ Migration to another region, especially at a large distance, would then foster intermarriage by providing the opportunity to meet people from different backgrounds ( $\left.\mathrm{H}_{5} \mathrm{a}\right)$. However, in some cases (the elite of small villages for example) it might be necessary to migrate to find a partner of approximately the same age and from the same social class, and indeed the geographical marriage horizon of the elites is, generally speaking, large, although the same applies to servants. ${ }^{33}$ But we will assume that this latter case is an exception.

Again, the characteristics of the place of origin and destination might play a decisive role. First, if one migrates but ends up in a place similar in terms of composition to one's place of origin (from rural village to rural

29. Segalen, Love and Power in the Peasant Family, p. 38.

30. Ibid., p. 4I.

31. Segalen, De l'amour et du mariage autrefois, pp. 68, 85. See too George Alter, Family and the Female Life Course: The Women of Verviers, Belgium, I849-I880 (Madison, WI, I988), pp. I $48-150$, on the town of Verviers.

32. P.M. Blau and J.E. Schwartz, Crosscutting Social Circles (New York, I984). William R. Catton, Jr and R.J. Smircich, "A Comparison of Mathematical Models for the Effect of Residential Propinquity on Mate Selection”, American Sociological Review, 29 (1964), pp. 522529. Stevens, "Propinquity and Educational Homogamy".

33. Pooley and Turnbull, Migration and Mobility in Britain since the I8th Century, p. I 58. 
village for example), then migration might have little effect on endogamy $\left(\mathrm{H}_{5} \mathrm{~b}\right) .{ }^{34}$ Secondly, if one migrates from a village to a city, the marriage market increases enormously; migrating in the opposite direction, there is little to be gained in terms of the number of potential marriage partners $\left(\mathrm{H}_{5} \mathrm{c}\right)$. These marriage-market hypotheses are also supported if members of large classes of origin marry endogamously more often than members of small classes of origin $\left(\mathrm{H}_{5} \mathrm{~d}\right)$. We will investigate whether this is the case.

Conversely, migration might also restrict the opportunities of migrants, if, for example, migrants and the original population do not interact. In that case migrants are forced to marry among themselves. This might restrict their choices, especially if they are a small group. Also, in this case migration will result in a higher degree of geographical endogamy but also a lower degree of social endogamy. Segregation of migrants and the original population is more likely to happen if both groups have a different lifestyle or if the original population feels threatened (economically or culturally) by the migrants. We may assume that lifestyle differences increase with the distance migrated (H6a) and with the relative degree of urbanization between the place of origin and destination of the migrants (H6b).35 Fear of migrants might be positively related to the size of the migrant group. ${ }^{36}$ However, because it is easier for larger migrant groups to find an appropriate partner within their own group, the result of this is unclear.

Some characteristics of society changed so much during the nineteenth and twentieth centuries that hypotheses formulated for the nineteenth century might no longer be true in the twentieth century, and vice versa. First, distance measured in kilometres (rather than time) meant something very different in the early nineteenth century from what it did in the late twentieth century. ${ }^{37}$ Whereas it once took weeks to travel from northern to southern France, this distance can now be covered in a day by car and even faster by aeroplane. We therefore expect distance to play a much smaller role in explaining endogamy today than it did two centuries ago $\left(\mathrm{H}_{7}\right)$.

Secondly, as a consequence of improved transportation, but also of the mass media, differences in norms and lifestyles between rural and urban areas have become narrower. Even the occupational distribution in villages and cities sometimes hardly differs any more. All hypotheses predicting an effect resulting from moving between rural and urban areas should

34. Morgan, "A Contribution to the Debate on Homogamy, Propinquity, and Segregation".

35. See for example, Bart Van de Putte, "Het belang van de toegeschreven positie in een moderniserende wereld. Partnerkeuze in $19^{\mathrm{de}}$-eeuwse Vlaamse steden (Leuven, Aalst en Gent)", (Ph.D., Catholic University of Leuven, 2003).

36. Hubert M. Blalock, Toward a Theory of Minority Group Relations (New York, 1967).

37. See for example Pooley and Turnbull, Migration and Mobility in Britain since the I8th Century, p. 303 . 
therefore be less valid now than they would have been in the early nineteenth century. More specifically, we expect decreasing effects of the difference in urbanization between the places of origin and destination $(\mathrm{H} 8)$ and the degree of urbanization of the place of destination $(\mathrm{H} 9)$.

Hypotheses 7, 8, and 9 also follow from the claim that social control has decreased in Europe in general and France in particular since the end of the eighteenth century. ${ }^{8}$ Flandrin stated that:

[...] la multiplication des conceptions prenuptials vient de ce que les jeunes gens ... ont alors été moins soumis a leurs parents que dans le passé; ils ont fréquenté plus librement les filles; ils ont davantage choisi leur future épouse par attrait sexuel et ont imposé plus souvent ce choix à leurs parents. ${ }^{39}$

Shorter claimed that "the most important change in nineteenth- and twentieth-century courtship has been the surge of sentiment [...]. People started to place affection and personal compatibility at the top of the list of criteria in choosing marriage partners. These new standards became articulated as romantic love." $4 \circ$ And he added: "Once the heart began to speak, it would give instructions often entirely incompatible with the rational principles of family interest and material survival on which the small community was ordered. Marry the woman you love, the heart might say, even though your parents disapprove." 4 I

Others have argued that social control was less in evidence in cities although by no means absent there, especially among the bourgeoisie than it was in the countryside ${ }^{42}$ and thus the continuous growth in the percentage of the population living in cities would mean that, over all, social control decreased in France over the past two centuries. We also know that veillées, bundling, and charivari are now virtually absent in France, while they were common at the beginning of the nineteenth century, and thus in the countryside too the degree of social control over the choice of marriage partner must have diminished. The charivari declined in number and force during the nineteenth century, so much so that by the end of the century it could be found only in small remote places. ${ }^{43}$ Although they remained a feature in many places until the i 880 s, by the turn of the century the veillées too were wasting away. ${ }^{44}$ And with them went the collective oral wisdom, ${ }^{45}$ codified in proverbs, which had

\footnotetext{
38. Flandrin, Les amours paysannes; J.M. Phayer, Sexual Liberation and Religion in Nineteenth Century Europe (London, 1977); Shorter, The Making of the Modern Family, pp. I25-127; James F. Traer, Marriage and the Family in Eighteenth-Century France (Ithaca, NY, 1980).

39. Flandrin, Les amours paysannes, p. 243.

40. Shorter, The Making of the Modern Family, p. I48.

41. Ibid., pp. 19-20.

42. Tilly and Scott, Women, Work and Family, p. I2 I I.

43. Weber, Peasants into Frenchmen, p. 406.

44. Ibid., p. $4 \mathrm{I} 6$.

45. Ibid., pp. 419-428.
} 
long expressed and enforced the desire for endogamy. Still, in remote areas of France, a strong sense of "us" versus "strangers" continued to exist until the I950s..$^{46}$ All told, however, we predict that the effect of social control and thus the difference in endogamy between migrants and non-migrants diminished over time.

These hypotheses are summarized in Table I.

\section{DATA, MEASUREMENT, AND MODELS}

\section{Data}

The data we use are drawn from the "3,000 families survey", better known as the TRA dataset. The name originates from the sample procedure used in the survey. The survey aims to collect birth, marriage, divorce, and death certificates for all French persons whose surnames begin with the three letters TRA (e.g. Tranchant, Travers). This results in patronymic genealogies of about 3,000 couples who married between I 803 and I 832 and a sample rate of about one per I0,000 inhabitants in I 806 . TRA was chosen because surnames starting with these three letters occur in all languages spoken in France (including Alsatian, Breton, Catalan, and French itself). For this research we use marriage register information. All marriages for the nineteenth century have been computerized. The dataset for the twentieth century is not yet complete. ${ }^{47}$ The dataset includes 74,562 marriage certificates. However, because information on crucial characteristics, especially the father's occupation, is missing from many certificates, models will be estimated using data from 23,64I marriage certificates for men and 23,3 I 3 marriage certificates for women.

\section{Measurement}

Endogamy is measured by comparing the social class of the father of the bride with the social class of the father of the groom at the time of the marriage. To arrive at the class variable, all occupational titles were first coded using HISCO..$^{8}$ These codes were then automatically recoded using

46. Claude Karnoouh, "L'étranger ou le faux inconnu. Essai sur la définition spatiale d'autrui dans un village lorrain", Ethnologie française, 2 (1972), pp. 107-I 22.

47. Analyses (not shown in this article) show that weighting the data to take the lower representation of rural areas in the twentieth century into account has no effect on the results. We therefore refrain from presenting results of analyses based on weighted data.

48. Marco H.D. van Leeuwen, Ineke Maas, and Andrew Miles, HISCO: Historical International Standard Classification of Occupations (Leuven, 2002). J.-P. Pélissier, D. Rébaudo, and D. Nicolas, "La mobilité professionnelle en France aux XIX et XXe siècles d'après les actes de mariage" [HISMA. Occasional Papers and Documents] (IISG, Amsterdam, 2004). 


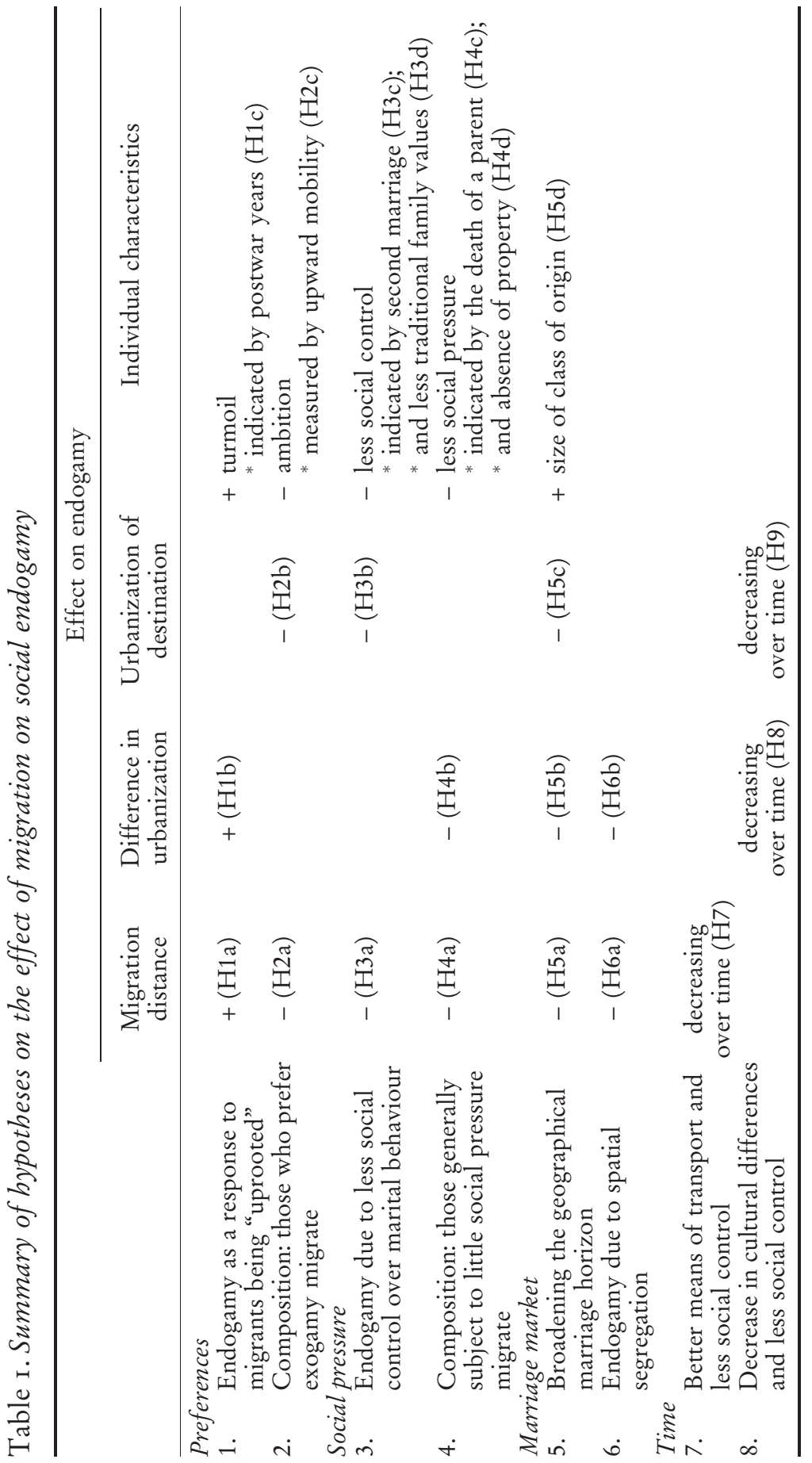




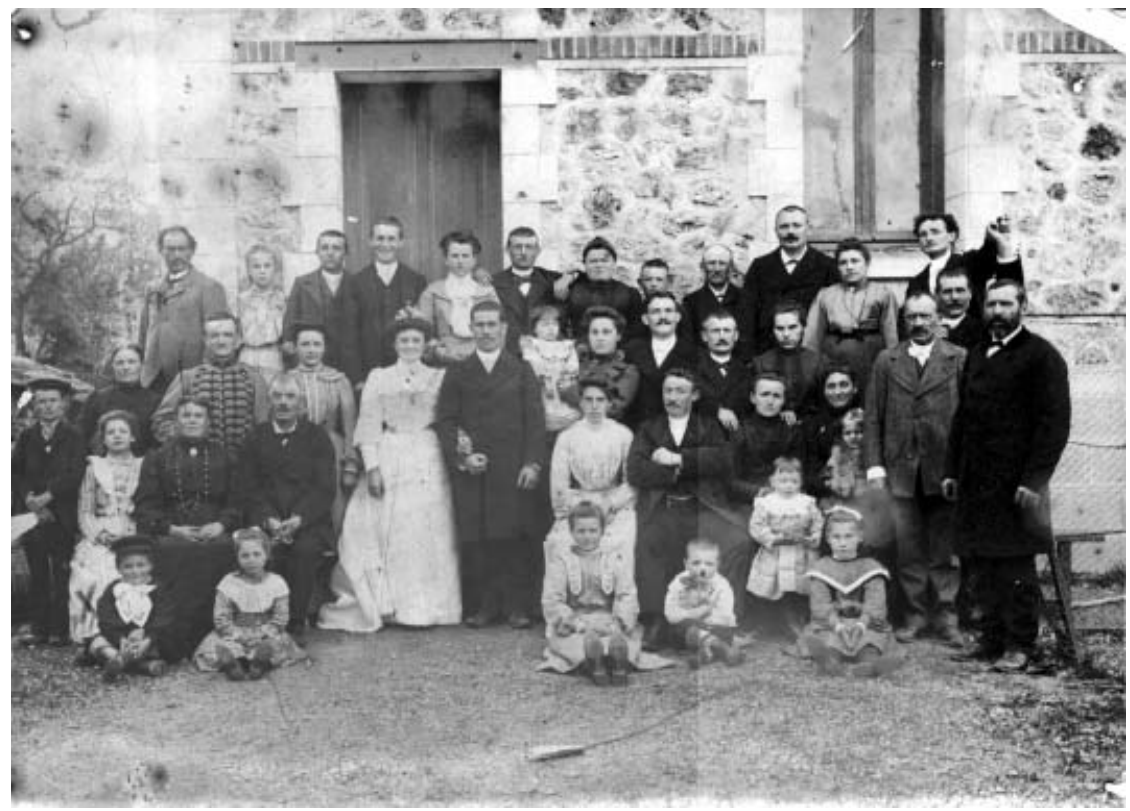

Figure I. Portrait of a marriage in Oeuilly (Marne), I905. Bride, groom, their parents, and relatives all lived in three villages situated five kilometres from one another. They were farmers or farm workers.

Source: Private collection D. Rébaudo. Used by permission.

HISCLASS. ${ }^{49}$ This taxonomy comprises twelve classes ranging from higher managers to unskilled farm workers. For reasons of comparability these twelve classes were combined into seven classes: $(I+2)$ higher managers and professionals, $(3,4,5)$ lower managers, professionals, clerical and sales, $(6,7)$ skilled workers, (8) farmers and fishermen, (9) lowerskilled workers, (I I) unskilled workers, and (Iо, I 2) farm workers.

In this type of source, information on the occupation of the father is usually missing in about 50 per cent of all cases. Since this is true for both the father and the father-in-law, valid cases for about 25 per cent of all marriages could be expected. Actually, endogamy was apparent in 26,480 cases, which is clearly above what we expected. Although the likelihood of having complete information on the classes of the father and the father-inlaw is greater for the stable rural population, the dataset contains enough

49. M.H.D. van Leeuwen and I. Maas, "HISCLASS", Paper presented at the sth European Social Science History Conference (Berlin, 24-27 March 2004); I. Maas and M.H.D. van Leeuwen, "SPSS Recode Job from HISCO into HISCLASS”, May 2004. 
cases of complete information on urban migrants to allow us to estimate our models.

Migration distance is operationalized as the distance in kilometres between the place of birth and place of residence at the time of marriage. Although the way this crucial concept of geographical "distance" is measured is both clear as well as generally valid, there might be a few less fortunate aspects to it. To begin with, differences in topography and accessibility between places are not taken into account, even though a mountain range or a major watershed can make places that are close to one another on a map very distant in terms of access. ${ }^{50}$ Furthermore, if the two places are identical, the migration distance will be zero, even in the case of a large city like Paris, where there might have been a sizeable distance between the actual address at birth and the address at marriage. This presumably presents only a small problem, but another characteristic of these migration-distance data is potentially more disturbing: about half the individuals were immobile; in half the cases the value for migration is zero. We therefore add a dummy variable distinguishing migrants from nonmigrants. The effect of migration distance then only applies to those who actually migrated.

Urbanization is measured using a five-category scale in increasing order of urbanization: rural towns and villages, capital of a canton, capital of an arrondissement, capital of a département, or department, and the national capital, Paris. The level of urbanization of the place of birth is unknown for those born abroad and for a small percentage of the rest of the population. They are excluded from our analyses. We measure the difference in urbanization between place of birth and residence by subtracting the category scores. The maximum difference is 4 (between Paris and rural towns and villages), the minimum is 0 .

During the nineteenth and twentieth centuries France was involved in several wars (I8I2-I8I5: the Napoleonic Wars; i870-I87I, the FrancoPrussian War; I9I4-I918: World War I; I939-I945: World War II). We believe that marriages in the years immediately after these wars would have been especially affected. Postwar years are distinguished from other years by a dummy variable.

Upward mobility is measured by comparing the class of the father of the groom/bride with the class of the bride/groom when the latter married. In both cases the seven-class version of HISCLASS is used, in which mobility from classes at the bottom of this taxonomy to classes higher up is regarded as upward mobility. Because a large proportion of women and a smaller proportion of men had no occupation at marriage, we add an extra dummy

50. R.J. Johnston and P.J. Perry, "Déviation directionelle dans les aires de contact: deux exemples de relations matrimoniales dans la France rurale du XIXe siècle”, Études Rurales, ${ }_{4} 6$ (1972), pp. 23-33. 
variable to distinguish these groups from men and women who did have an occupation at marriage.

French marriage registers give information on the survival status of the parents. We measure separately whether the father is deceased and whether the mother is deceased. Two classes are deemed to have had property: the higher managers and professionals (class $\mathrm{I}+2$ ) and the farmers and fishermen (class 8). As this is a proxy variable, not all members of these classes will in effect have had property. There must have been a certain proportion without property, especially among the very large class of farmers. The occupational titles seldom make this clear however (if they did, there would be no problem; not only does the HISCLASS taxonomy place cotters among the group of rural labourers and large landowners among the elite, HISCO itself has a subsidiary variable noting property). Although there is thus a certain amount of "noise" in the data, it is reassuring that other French data make it clear that a large proportion of farmers and the elite did, generally speaking, leave something to inherit at their death. ${ }^{\text {I }}$ First marriages of brides and grooms are distinguished from second and later marriages.

Having traditional family values has not been measured at the individual level. Instead, we used information from Todd on departmental differences in family values..$^{2}$ France consists of almost Ioo departments. They have all been scored on the relationship between parents and children (more or less authoritarian) and the relationship between siblings (more or less egalitarian). Both characteristics have been combined into three categories: (O) egalitarian and not very authoritarian; (I) either authoritarian or inegalitarian; and (2) authoritarian and inegalitarian. These departmental characteristics have been linked to the individuals by using the department in which they were born.

Class size is measured by the percentage of brides' fathers that belong to

51. Luc Arrondel and Cyril Grange, "Successions et héritiers dans la société rurale du XIXe siècle: l'exemple des familles 'TRA' de Loire-Inférieure”, Annales de Démographie Historique (2004), pp. 53-77.

52. Emmanuel Todd, La nouvelle France (Paris, I988), p. 88. Todd claims his data are valid for at least the past two centuries. It should be noted though that he does not break them down by subperiod. Although we are fortunate in having a measure of traditional family values at all, we would have preferred to have had more than one measurement point (and to have had individuallevel rather than departmental-level data). As we cannot distinguish between sub-periods, it is unclear if there were changes in the position of departments relative to one another with regard to family values. Preliminary results from a national survey in 1980 among French notaries concerning the transmission of property in villages and small cities seem to suggest stability. This, at least, is Goy's conclusion ("la permanence, près de deux siècles après la promulgation du Code civil des comportements régionaux pré-1789 malgré les transformations juridiques, économiques et sociologiques"). See Joseph Goy, "Pour une cartographie des modes de transmission successorale deux siècles après le Code civil", Mélanges de l'École française de Rome, I00 (1988), pp. 43I-444; the quotation is on p. 44I. 
a specific class. Class size is estimated separately for every five years. Since class and the sex of the children are not correlated, this percentage is a good indicator of the availability of partners for both men and women.

Finally, we take the year of marriage into account because it is generally assumed that endogamy of class of origin decreased over time. To test hypotheses on the changing importance of migration over time, interaction effects of year of marriage and migration distance, urbanization of the place of residence, and difference between urbanization of place of birth and place of residence respectively are created. Before these variables were multiplied, they were centred around their mean. As a consequence, the main effect of - say - migration distance in models including the interaction effect of migration distance and year of marriage can be interpreted as the effect of migration distance in the mean year of marriage (around I900).

\section{Models}

Because the dependent variable has only two categories, we use logistic regression analyses. In the first model only migration characteristics (distance, urbanization of place of residence, and difference in urbanization between places of birth and residence) are included. In a second model, individual characteristics are added. In a third model, interaction effects between the migration characteristics and time are included. A separate set of logistic regression models is used to investigate to what extent changes in the migration characteristics explain trends in the likelihood of endogamy. We present exponentiated effect parameters, socalled odds ratios. Odds ratios above I indicate positive effects; odds ratios between $\circ$ and I indicate negative effects.

\section{RESULTS}

\section{Description}

Before we disentangle the effects of several migration characteristics and other variables, we investigate whether migration and endogamy are related. A comparison between migrants and non-migrants with respect to the percentage of marriages that were endogamous offers preliminary support for a strong relationship. Whereas only 40 per cent of male and female migrants married within their own class of origin, 53 per cent of male non-migrants and 52 per cent of female non-migrants did so (Table 2). The longer the distance migrated, the greater the likelihood of an exogamous marriage. Male migrants who married exogamously migrated over an average distance of 96 kilometres, while for those who married endogamously the average distance migrated was only 69 kilometres. For 
Table 2. Migration and social endogamy in France, I803-1986

\begin{tabular}{lcc}
\hline & Men & Women \\
\hline Endogamous marriages (\%) & & \\
$\quad$ migrants & 40.1 & 40.1 \\
$\quad$ non-migrants & 53.4 & 51.8 \\
Migration distance (mean km, migrants only) & & \\
$\quad$ endogamous & 69.4 & 59.6 \\
$\quad$ exogamous & 96.1 & 79.1 \\
Endogamous marriages (\%) & & \\
$\quad$ urban-rural migrant & 33.2 & 31.2 \\
$\quad$ urban-urban migrant & 32.4 & 29.6 \\
$\quad$ rural-urban migrant & 29.9 & 29.1 \\
$\quad$ rural-rural migrant & 53.3 & 48.7 \\
\hline
\end{tabular}

Source: TRA survey, INRA/CNRS.

female migrants the difference was somewhat less (79 kilometres compared with 60 kilometres), but still substantial.

An initial investigation of the direction of migration reveals two different types of migrant. Those who migrated from one rural place to another differed from non-migrants hardly at all with respect to the likelihood of endogamy. All migrants who moved either to or from a city were much less likely to marry endogamously. The patterns for men and women are strikingly similar.

Finally, we investigate whether the relationship between migration and endogamy changed over time (Figure 2). Figure 2 shows two interesting patterns. First, the likelihood of marrying endogamously changed little during the nineteenth century, but decreased thereafter. Secondly, around 1930 the marriage patterns of migrants and non-migrants converged slightly. Before I930 the "spread" between endogamous marriages among migrants and non-migrants tended to be about ro per cent. After I930, this slowly decreased to about 5 per cent in 1986.

\section{Models}

Tables 3 and 4 present the logistic regression models for men and women respectively. We will describe the results in the order of the hypotheses listed in Table I. According to the first hypothesis, endogamy should increase with the distance migrated because migrants feel more uprooted than non-migrants, especially when they migrate over a long distance (Нia). We find no support for this hypothesis. In all models for men and women there is a clear negative relationship between being a migrant and endogamy: migrants were less likely than non-migrants to marry endogamously. However, distance did not seem to matter: none of the 


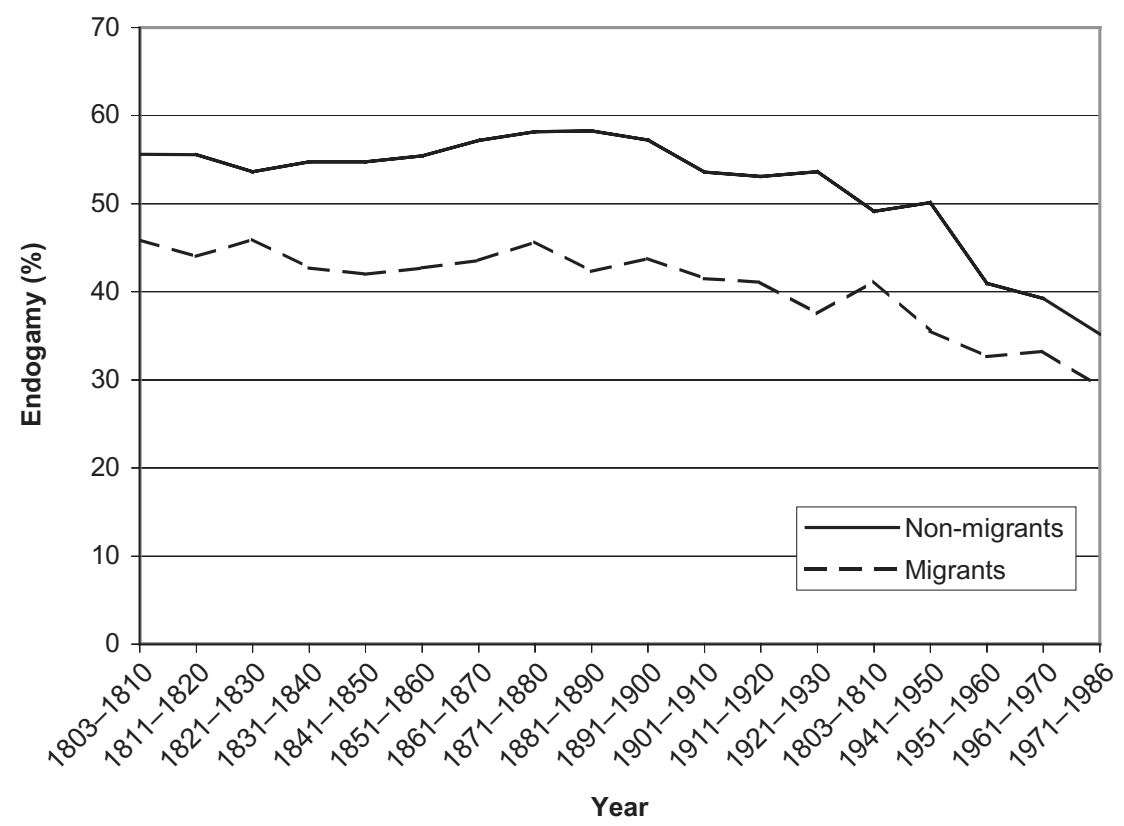

Figure 2. Social endogamy of migrants and non-migrants in France, I803-1986. TRA survey, INRA/CNRS

effects of migration distance is significant. This means that although we found a bivariate negative association between distance migrated and endogamy, this association is caused by the fact that men and women who migrated over a large distance were also more likely to migrate to a city and to migrate between places that differed greatly with respect to urbanization (the two other variables in model I).

According to the first preference hypothesis, migrants who migrated between places that differed greatly with respect to urbanization should also feel more uprooted and be more likely to marry endogamously ( $\mathrm{Hib}$ ). Again, we find the opposite for both men and women. The greater the difference in urbanization, the less likely the marriage would be endogamous. A I-point difference on the urbanization scale leads to an odds ratio of 0.955 for men and 0.909 for women. The odds of men who migrated between rural villages and Paris marrying endogamously were $0.832\left(0.955^{4}\right)$ times the odds of men who migrated between places with the same level of urbanization. The corresponding odds for women were $0.683\left(0.909^{4}\right)$.

Finally, the first preference hypothesis predicted that men and women would be more likely to marry endogamously in postwar years than in 
Table 3. Logistic regression analyses of social endogamy in France, I8031986 (men)

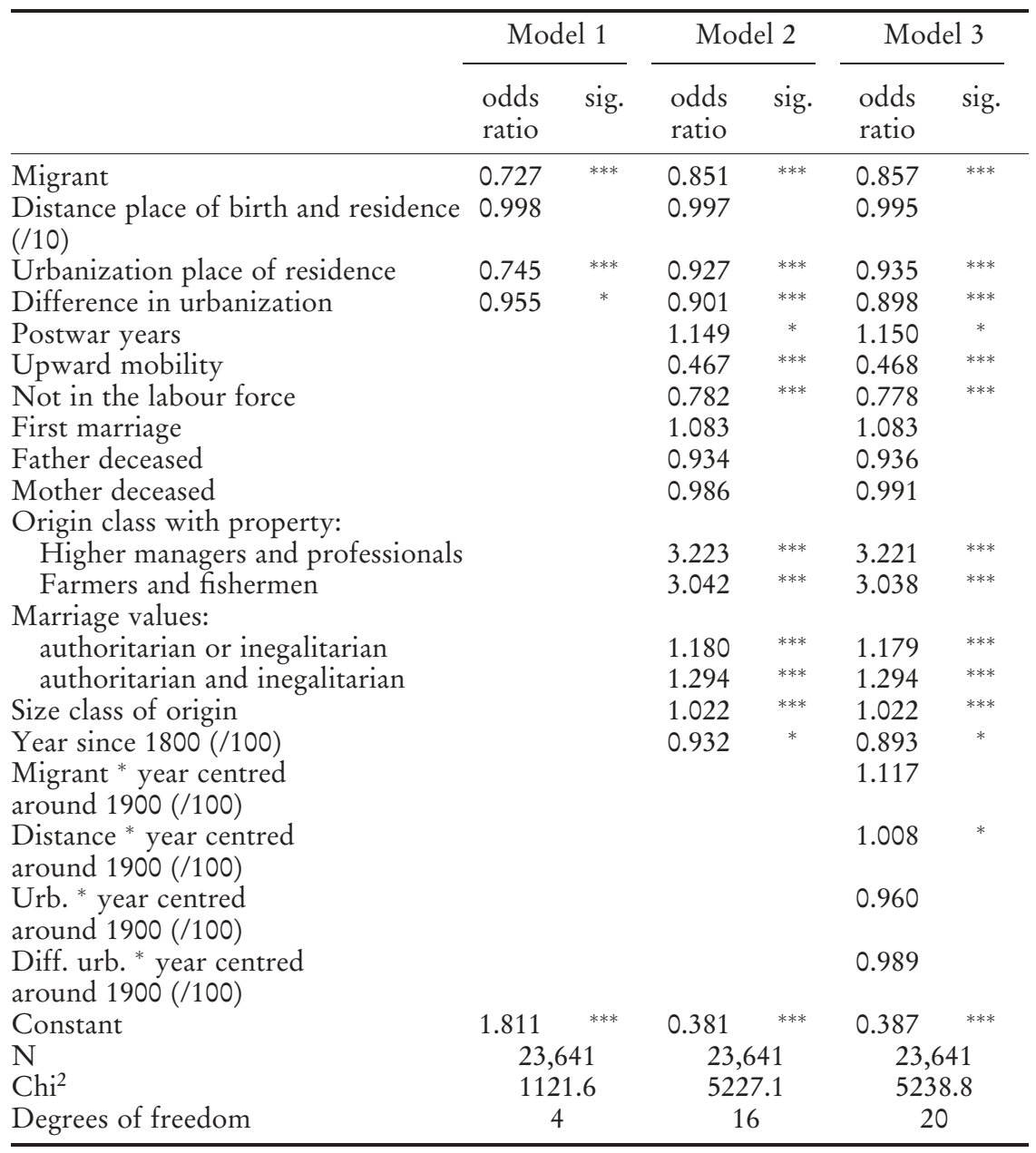

Source: TRA survey, INRA/CNRS.

* $\mathrm{p}<0.05 ;{ }^{* *} \mathrm{p}<0.0 \mathrm{I},{ }^{* * *} \mathrm{p}<0.00 \mathrm{I}$.

other years (Hic). We find some support for this hypothesis in the case of men. In the years immediately following a war, the odds of men marrying endogamously were is per cent higher than the corresponding odds in other years. Women seemed less affected by war and its aftermath. ${ }^{53}$

53. Interestingly, for Britain, Pooley and Turnbull found that wars had little permanent effect on migration patterns; while wars did result in population movements, after the war most people returned home; Pooley and Turnbull, Migration and Mobility in Britain since the 18th Century, pp. $26 \mathrm{I}, 273$. 
Table 4. Logistic regression analyses of social endogamy in France, I803I986 (women)

\begin{tabular}{|c|c|c|c|c|c|c|}
\hline & \multicolumn{2}{|c|}{ Model 1} & \multicolumn{2}{|c|}{ Model 2} & \multicolumn{2}{|c|}{ Model 3} \\
\hline & $\begin{array}{l}\text { odds } \\
\text { ratio }\end{array}$ & sig. & $\begin{array}{l}\text { odds } \\
\text { ratio }\end{array}$ & sig. & $\begin{array}{l}\text { odds } \\
\text { ratio }\end{array}$ & sig. \\
\hline Migrant & 0.793 & $* * *$ & 0.916 & ** & 0.918 & $*$ \\
\hline $\begin{array}{l}\text { Distance place of birth and residence } \\
(/ 10)\end{array}$ & 1.002 & & 1.002 & & 1.000 & \\
\hline Urbanization place of residence & 0.745 & $* * *$ & 0.932 & $* * *$ & 0.937 & $* * *$ \\
\hline Difference in urbanization & 0.909 & $* * *$ & 0.863 & $* * *$ & 0.860 & $* * *$ \\
\hline Postwar years & & & 1.077 & & 1.078 & \\
\hline Upward mobility & & & 0.604 & $* * *$ & 0.604 & $* * *$ \\
\hline Not in the labour force & & & 0.757 & $* * *$ & 0.755 & $* * *$ \\
\hline First marriage & & & 1.188 & $*$ & 1.188 & $*$ \\
\hline Father deceased & & & 0.982 & & 0.982 & \\
\hline Mother deceased & & & 0.979 & & 0.981 & \\
\hline \multicolumn{7}{|l|}{ Origin class with property: } \\
\hline Higher managers and professionals & & & 2.537 & $* * *$ & 2.539 & $* * *$ \\
\hline Farmers and fishermen & & & 2.832 & $* * *$ & 2.829 & $* * *$ \\
\hline \multicolumn{7}{|l|}{ Marriage values: } \\
\hline authoritarian or inegalitarian & & & 1.266 & $* * *$ & 1.265 & $* * *$ \\
\hline authoritarian and inegalitarian & & & 1.369 & $* * *$ & 1.369 & $* * *$ \\
\hline Size class of origin & & & 1.027 & $* * *$ & 1.027 & $* * *$ \\
\hline Year since $1800^{\circ}(/ 100)$ & & & 0.899 & ** & 0.886 & $*$ \\
\hline $\begin{array}{l}\text { Migrant * year centred } \\
\text { around } 1900(/ 100)\end{array}$ & & & & & 1.047 & \\
\hline $\begin{array}{l}\text { Distance * year centred } \\
\text { around } 1900(/ 100)\end{array}$ & & & & & 1.005 & \\
\hline $\begin{array}{l}\text { Urb. }{ }^{*} \text { year centred } \\
\text { around } 1900(/ 100)\end{array}$ & & & & & 0.971 & \\
\hline $\begin{array}{l}\text { Diff. urb. }{ }^{*} \text { year centred } \\
\text { around } 1900(/ 100)\end{array}$ & & & & & 1.007 & \\
\hline Constant & 1.706 & $* * *$ & 0.328 & $* * *$ & 0.328 & $* * *$ \\
\hline $\mathrm{N}$ & \multicolumn{2}{|c|}{23,313} & \multicolumn{2}{|c|}{23,313} & \multicolumn{2}{|c|}{23,313} \\
\hline $\mathrm{Chi}^{2}$ & \multicolumn{2}{|c|}{1018.7} & \multicolumn{2}{|c|}{5011.9} & \multicolumn{2}{|c|}{5014.9} \\
\hline Degrees of freedom & \multicolumn{2}{|c|}{4} & \multicolumn{2}{|c|}{15} & \multicolumn{2}{|c|}{20} \\
\hline
\end{tabular}

Source: TRA survey, INRA/CNRS.

${ }^{*} \mathrm{p}<0.05 ;{ }^{* *} \mathrm{p}<0.0 \mathrm{I} ;{ }^{* *} \mathrm{p}<0.00 \mathrm{I}$.

According to the second preference hypothesis, the distance migrated should be negatively related to endogamy, because those who were keenest to escape their local fate migrated over a large distance and were also less likely to marry endogamously $\left(\mathrm{H}_{2} \mathrm{a}\right)$. As discussed above, there is indeed a negative relationship between being a migrant and endogamy, but not between distance migrated and endogamy. More consistent with this hypothesis is the negative relationship between urbanization of place of 
residence and endogamy for both men and women ( $\left.\mathrm{H}_{2} \mathrm{~b}\right)$. This relationship is rather strong in model I. For both men and women a I-point difference on the scale of urbanization of their place of residence is associated with 25 per cent lower odds of marrying endogamously. Those living in Paris were 68 per cent less likely to marry endogamously than those living in rural villages.

The second preference hypothesis also predicts that the differences in marital patterns between cities and villages would disappear if we took the ambitions of men and women into account $\left(\mathrm{H}_{2} \mathrm{c}\right)$. This is very hard to do with the data at hand, but we may assume at least that men and women who are upwardly mobile compared with their father are more ambitious. This variable is included in the second model. Upwardly mobile men and women were indeed much less likely to marry endogamously than men and women who were not mobile, not even downwardly.

The association between endogamy and urbanization of the place of residence is much smaller in the second model than in the first. However, models in which the variables of model 2 are excluded one by one (results not shown in the tables) show that upward mobility explains only a very small part of this change. ${ }^{54}$ Together, these results may be summarized as follows. The negative relationships between endogamy on the one hand and being a migrant and urbanization of place of residence on the other seem to support the second preference hypothesis, namely that those who preferred to marry exogamously migrated. However, the finding that these relationships are "explained" hardly at all by the ambitions of men indicates that it might be fruitful to search for other explanations for these negative relationships - explanations perhaps formulated in some of the other hypotheses.

According to hypothesis 3, the social pressure of family and peers weakened due to migration $\left(\mathrm{H}_{3} \mathrm{a}\right)$, and this was especially the case for those who migrate toward a city $\left(\mathrm{H}_{3} \mathrm{~b}\right)$. This hypothesis is thus also consistent with the negative relationships between being a migrant and endogamy, and between urbanization of place of residence and endogamy. We expected social pressure to weaken between first and second marriages. This was the case for women. The odds of a woman's first marriage being endogamous were I9 per cent higher than the odds of a second or later marriage being endogamous. This is additional support for the hypothesis that under certain circumstances family and peers were less able to affect marriage behaviour. Finally, social pressure of family and peers on marriage behaviour is expected to be stronger for persons originating from a department with more traditional family values $\left(\mathrm{H}_{3} \mathrm{~d}\right)$. Our findings support this hypothesis. Men and women born in departments

54. If upward mobility is omitted, the effect of urbanization of place of residence of men in model 2 becomes 0.916 , which is much closer to 0.927 than to 0.745 . 
where family values are more traditional were more likely to marry someone from the same class of origin. 55

According to the rival hypothesis on social pressure, those who migrate are a select group of people who experienced little social pressure before migration. Based on this hypothesis, both migration distance $\left(\mathrm{H}_{4} \mathrm{a}\right)$ and the difference in the level of urbanization $\left(\mathrm{H}_{4} \mathrm{~b}\right)$ are expected to be negatively related to endogamy. As discussed above, the difference in the level of urbanization was indeed negatively related to endogamy and migrants in general were more likely to marry outside their class of origin.

This second social-pressure hypothesis also predicts, though, that these relationships should disappear if we take initial differences in social pressure into account. We do so by adding to the model a variable indicating whether the parents were alive at marriage $\left(\mathrm{H}_{4} \mathrm{c}\right)$, and whether the parents belonged to the propertied classes $\left(\mathrm{H}_{4} \mathrm{~d}\right)$. The survival status of the parents does not show the predicted effect, but in the models family property has the predicted relationship with endogamy. Women, and especially men, from the propertied classes were much more likely to marry endogamously than women and men from other classes. However, these characteristics do not completely explain the effects of being a migrant and the difference in urbanization between place of birth and residence. The effect of the latter variable in particular hardly differs between models I and 2. People who experienced little social pressure were more likely to marry outside their own social class, but they were not more likely to migrate between places that differed much with respect to urbanization. ${ }^{56}$

Both of the two marriage-market hypotheses predict negative relationships between distance migrated and difference in urbanization (between place of birth and residence) on the one hand and endogamy on the other. According to the first marriage-market hypothesis, a negative relationship may be expected because those who married over a large distance, or moved to a larger city, or moved between places that differed strongly, were more likely to meet people from a different social background ( $\mathrm{H}_{5} \mathrm{a}$, $\mathrm{b}, \mathrm{c}$ ). According to the second marriage-market hypothesis, those who migrated over a large distance and between very different places would be more segregated from the population in the place of destination and would therefore be forced to marry among the migrant group. Given those restrictive circumstances it was probably more difficult to marry someone

55. The fact that family values were not measured at the individual level but at the level of department means that our non-multi-level analyses might overestimate the significance of their effect.

56. Note, however, that the effect of urbanization of place of residence is explained to a large extent by the smaller percentage of the population originating from a propertied, i.e. farming, class in the cities. 
from the same social background (H6a, b). With the exception of the effect of migration distance, these predicted relationships are borne out by the data.

According to the mechanism behind the first marriage-market hypothesis, men and women from larger social classes would be more likely to marry endogamously, because the likelihood of them meeting others from their own social background was relatively high $(\mathrm{H} / \mathrm{d})$. The positive effects of size of the class of origin on endogamy for both men and women support this hypothesis. If one class of origin is io per cent larger than another class, the odds of marrying endogamously in the first class will be 24 per cent higher for men and 3 I per cent higher for women than the corresponding odds in that other class.

Even after taking characteristics of migration and many individual characteristics into account, there is still an effect of year of marriage. In the early nineteenth century people were more likely to marry within their own class of origin than they were in the late twentieth century. We will return to this in the next section.

The last three hypotheses in Table I predict that the effects of migration will have decreased over time. In general, this is not what we find. Only the effect of long-distance migration decreased for men. We did not find an overall effect of migration distance on the likelihood of men marrying endogamously, evidently because this effect disappeared over time. ${ }^{57}$ Cultural differences, as indicated by differences in urbanization, are just as important predictors of endogamy in the nineteenth century as they are in the twentieth century.

\section{Explaining changes in endogamy over time}

In the introduction we assumed that changes in the likelihood, distance, and direction of migration might explain changes in rates of endogamy over time. For example, we found a rather strong negative effect on endogamy of the difference in urbanization between place of birth and place of residence. If this type of migration has become more frequent over time, this might explain the decrease in the likelihood of endogamy. To further investigate this, we estimate three more models (Tables 5 and 6). The first model shows the bivariate relationship between endogamy and the year of marriage. The second model includes the three migration variables, and the third model the other individual characteristics. A full model including all variables has already been shown in Tables 3 and 4 (model 2); this model shows a small unexplained trend toward less endogamy. 
Table 5. Explaining changes in social endogamy in France, 1803-1986 (men)

\begin{tabular}{|c|c|c|c|c|c|c|}
\hline & \multicolumn{2}{|c|}{ Model 1} & \multicolumn{2}{|c|}{ Model 2} & \multicolumn{2}{|c|}{ Model 3} \\
\hline & $\begin{array}{l}\text { odds } \\
\text { ratio }\end{array}$ & sig. & $\begin{array}{l}\text { odds } \\
\text { ratio }\end{array}$ & sig. & $\begin{array}{l}\text { odds } \\
\text { ratio }\end{array}$ & sig. \\
\hline Year since $1800(/ 100)$ & 0.633 & $* * *$ & 0.742 & $* * *$ & 0.843 & $* * *$ \\
\hline Migrant & & & 0.741 & $* * *$ & & \\
\hline $\begin{array}{l}\text { Distance place of birth and residence } \\
(/ 10)\end{array}$ & & & 0.999 & & & \\
\hline Urbanization place of residence & & & 0.751 & $* * *$ & & \\
\hline Difference in urbanization & & & 0.969 & & & \\
\hline Postwar years & & & & & 1.152 & * \\
\hline Upward mobility & & & & & 0.444 & *** \\
\hline Not in the labour force & & & & & 0.719 & *** \\
\hline First marriage & & & & & 1.134 & * \\
\hline Father deceased & & & & & 0.910 & $*$ \\
\hline Mother deceased & & & & & 0.974 & \\
\hline \multicolumn{7}{|l|}{ Origin class with property: } \\
\hline Higher managers and professionals & & & & & 3.256 & *** \\
\hline Farmers and fishermen & & & & & 3.484 & *** \\
\hline \multicolumn{7}{|l|}{ Marriage values: } \\
\hline authoritarian or inegalitarian & & & & & 1.160 & *** \\
\hline authoritarian and inegalitarian & & & & & 1.303 & $* * *$ \\
\hline Size class of origin & & & & & 1.020 & *** \\
\hline Constant & 1.358 & *** & 2.280 & $* * *$ & 0.311 & *** \\
\hline $\mathrm{N}$ & \multicolumn{2}{|c|}{23,641} & \multicolumn{2}{|c|}{23,641} & \multicolumn{2}{|c|}{23,641} \\
\hline $\mathrm{Chi}^{2}$ & \multicolumn{2}{|c|}{280.8} & \multicolumn{2}{|c|}{1231.4} & \multicolumn{2}{|c|}{5007.9} \\
\hline Degrees of freedom & \multicolumn{2}{|c|}{1} & \multicolumn{2}{|c|}{5} & \multicolumn{2}{|c|}{12} \\
\hline
\end{tabular}

Source: TRA survey, INRA/CNRS.

${ }^{*} \mathrm{p}<0.05$; $^{* *} \mathrm{p}<0.0 \mathrm{I}$; ${ }^{* *} \mathrm{p}<0.00 \mathrm{I}$.

The bivariate relationship between endogamy and year of marriage is strongly negative (see too Figure 2). The likelihood of an endogamous marriage decreased by about 37 per cent (I to 0.63 ) over Ioo years and by about 60 per cent during the whole period. The three migration variables explain a substantial part of this trend. For men, the effect of year of marriage weakened from 0.64 to 0.74 after taking migration into account; for women the effect changed from 0.63 to 0.73 . For both men and women this was due mainly to increasing numbers of men and women living in large cities (analyses not shown). The migration characteristics and the other variables offer separate (hardly overlapping) explanations of the trend toward less endogamy. This can be seen from the fact that the difference in the effect of year of marriage between models I and 2 (both in Tables 5 and 6) is of approximately the same size as the difference in the effect of year of marriage between model 3 in these tables and the full model (model 2 ) in Tables 3 and 4 . 
Table 6. Explaining changes in social endogamy in France, I803-1986 (women)

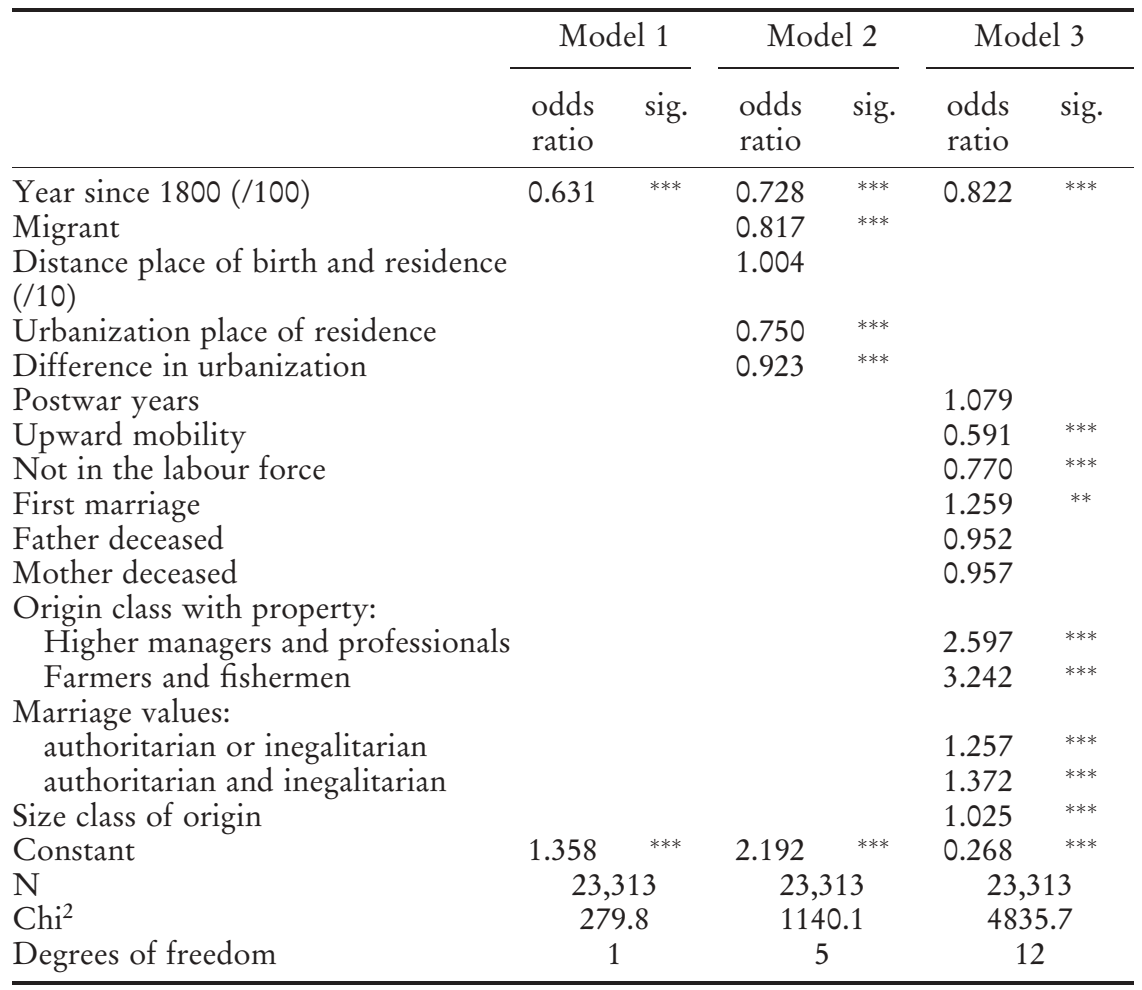

Source: TRA survey, INRA/CNRS.

${ }^{*} \mathrm{p}<0.05 ;{ }^{* *} \mathrm{p}<0.0 \mathrm{I}$; ${ }^{* *} \mathrm{p}<0.00 \mathrm{I}$.

Together, the other variables (model 3) explain a somewhat larger part of the trend than the migration characteristics. By far the most important are changes in class sizes (analyses not shown). At the beginning of the nineteenth century a very large proportion of the French population were farmers. As a consequence, the likelihood of a farmer's son meeting and eventually marrying a farmer's daughter was very high. At the end of the twentieth century the class structure was more heterogeneous, resulting in more contacts between members of different classes, and more exogamy.

\section{CONCLUSION}

The main aim of this article was to test hypotheses on the effects of migration on endogamy by social origin. We formulated six hypotheses. One of them predicted that endogamy would increase with the distance 
migrated, and with the difference in urbanization between place of birth and place of residence at marriage; five hypotheses predicted the opposite. The one exceptional hypothesis was not supported by our findings. Although people might have felt uprooted after migration, this was not followed by an increased likelihood of endogamy. Nevertheless, some support for the effect of feeling uprooted was found: men were more likely to marry endogamously in the years immediately following a war than in other years.

Of the remaining five hypotheses, two predicted that migration and endogamy would be negatively related because the group of migrants is composed differently from the group of non-migrants: with respect to preferences (ambitious people were more likely to migrate) and with respect to social pressure (individuals under less social pressure were more likely to migrate). These hypotheses are supported by several findings. First, we found that men and women who migrated were less likely to marry within their own class of origin. Secondly, for men, in the nineteenth century this was less likely in the case of long-distance migration. Thirdly, men and women were less likely to marry endogamously when they lived in cities and when they migrated between places that differed greatly with respect to urbanization (between rural villages and Paris for example). Furthermore, several indicators of ambition and social pressure show the predicted relationship with endogamy. Nevertheless, these two composition hypotheses are not fully supported because ambition and social pressure do little to explain the effects of migration characteristics.

There is support for the hypothesis that social pressure declines when men and women "move away" from their parents. Moving away can take the form of either migration, especially to a city, or a second marriage. Women (but not men) who remarried were more likely to marry someone from a different social background than women who married for the first time.

Finally, two hypotheses stated that migration should be negatively related to endogamy because migration affects the marriage market. Although the mechanisms behind these two hypotheses are very different (greater opportunity to meet others compared with forced marriage within the group of migrants), both predict the same relationship between migration and endogamy; and both are supported. The mechanism of greater opportunity to meet is also supported by the finding that endogamy was strongly related to size of class.

We conclude that migrants were less likely to marry endogamously, especially if they migrated from rural villages to cities; this is explained mainly by the fact that they thereby escaped the social pressure of their parents and peers and met more people from different social backgrounds.

Contrary to what we expected, the relationships between migration 
characteristics and endogamy changed hardly at all over the two centuries to which our data relate. One would expect it nowadays to be much easier for parents to visit their children even if they live elsewhere. It is also easier for men and women to meet people from different social backgrounds without having to migrate. Nevertheless, migration was almost as strongly related to endogamy at the end of the twentieth century as it was almost two centuries earlier.

Our second aim was to investigate whether temporal differences in endogamy could be explained partly by changes in migration patterns. We found that they could. The increase in the number of men and women living in or moving to cities was one particularly important cause of the decreasing likelihood of endogamy. Another was the more equal division of men and women across social classes.

Thirdly, we were interested in the possible bias in regional studies on endogamy. Our results show that this bias is especially large if these regions include only rural areas or cities. This is because the likelihood of endogamy differs between rural areas and cities, and is also especially low for people who move between these two types of region.

Finally, we were interested in the fate of migrants. Our finding that migrants were less likely to marry endogamously suggests that they were not fully integrated in their place of destination. Further analyses should reveal whether exogamy for migrants meant marrying upward or downward. 